\title{
EMPOWERMENT OF RURAL WOMEN FARMERS AND FOOD PRODUCTION IN IMBULPE DS DIVISION IN SRI LANKA: A HOUSEHOLD LEVEL ANALYSIS
}

\author{
Dilini Rathnachandra*, P Malkanthi \\ Faculty of Agricultural Sciences, Sabaragamuwa University of Sri Lanka, Sri Lanka \\ *corresponding author:dilinirathnachandr92@gmail.com
}

\begin{abstract}
Women empowerment and gender equity are two significant aspects of the sustainable development of a country. As Sri Lanka is on the way towards sustainable development, this study is conducted to identify women farmers' empowerment and food production in the country's Imbulpe (Divisional Secretariat) DS division. A sample of 300 women farmers was randomly selected for the study from seven selected Grama Niladhari divisions (GN) of the Imbulpe DS division. A field survey was carried out to data collection through a pre-tested, self-administered questionnaire from April to July 2019. Descriptive statistics, correlation analysis, and regression analysis, were used as the data analysis methods. Results convey that most women farmers were middle-aged, married and had two children within their family. Furthermore, most of the respondents had a secondary level of education and their average family size was four, 1.25 acres was the average farmland size. They had about 16 years of experience in the field of the agriculture sector. The average monthly income of the respondents was 25,000.00 LKR (Sri Lankan Rupees). Women empowerment was measured by using the models of Rahman and Naoroze (2007); Praveen and Leonhauser (2004) with necessary modifications according to the study area. According to the unit empowerment measures, most of the women farmers showed social empowerment aspect and political empowerment aspect reported as the least empowerment aspect. Out of the socio-economic factors size of the farm land, number of agricultural training programs participated, monthly income of the family, respondents level of education and number of agricultural training programs attended were indicated significant and positive effect for the empowerment of women farmers. Accessibility of credit facilities and agricultural extension program participation showed a considerable impact on food production rather than the cultivable land size and utilization of modern farming technologies for food production. Therefore, providing timely important agricultural education and training programs, enhancing awareness level of modern farming technology utilization, better micro finance programs, and agricultural credit facilities will be able to upgrade the level of empowerment of women farmers in Imbulpe DS division.
\end{abstract}

Keywords: Women empowerment, sustainable development, gender equity, farming activities, Sri Lanka

http://dx.doi.org/10.21776/ub.agrise.2022.022.1.6

Received 8 June 2021

Accepted 25 January 2022

Available online 31 January 2022

\section{INTRODUCTION}

According to the Developmental Goals (DG), the women empowerment is a basic concept to the emergence of poverty alleviation programs in a particular country (Ibharhokanrhowa, 2016). Women empowerment is a process of enhancing the freedom of decision making within the family, access to assets and resources, social participation, freedom of mobility and spending ability (Rathnachandra \& Malkanthi, 2020; Rahman \& Naozore, 2007). The potentials for agriculture accountable for the buildup of a proper avenue to unleash people's well-being through food production.

In Sri Lanka, more than half of the working population is constituted of women. And also, the share of economically active women is $18 \%$ from the total working age population. Among them $80 \%$ of economically women represent from the rural area. But the rural area consists with the largest unemployment rate of women compared with the urban and estate sectors. Sri Lanka is predominantly 
an agriculturally based country with $82 \%$ of the households still in the rural sector. Women constitute $50.7 \%$ of the Sri Lankan population are considered a valuable resource potential needed to be in the rural agricultural sector. Women contribution to agriculture is gradually increasing to the national economy. Most Sri Lankan women participated in the agricultural sector rather than the industrial sector (Annual labor force reports, 2017). Measuring the empowerment status of rural women and food production is timely important to make future decisions for achieving sustainable development related to social, economic, and Environmental aspects. Most of the researchers are only focusing on measuring the women empowerment and diagnosing the factors behind the empowerment of women. But in this research mainly clarify about the women which engaging in farming activities how create deviation on agricultural sector through achieving the overall empowerment in the society. Rural women are highly contributed to the agricultural activities in Sri Lanka. But with most of them don't have necessary power and facilities to do the work well. In some households, men are working in cities. Women have to do household activities and also agricultural activities. If they have sufficient empowerment, they can contribute to rural development up to a significant level. However, it is important to understand the issues consisting of the background related to accessing women farmers' empowerment. These are the key aspects which constitute the attention on this study. Therefore, this study was conducted to find out the situation of women farmers' empowerment and what sources of empowerment are relevant to the women famers in the study area. Empowerment is calculated by using five dimensions according to the literature findings relevant to empowerment.

\section{Food security and production in a global point of view}

The concept of food security is a target goal of United Nations Sustainable Development, which is valid during 2015 2030. Most developing countries have common critical issues, such as unavailability of foods for consumption or food insecurity. According to the World Food Conference demonstrations, evidence that a wide range of crop failures and disasters causes food insecurity (FAO, 2018). Maxwell and Smith (1996) recorded the other factors responsible for food insecurity. Such as; (a) Shortages of agricultural production and supply; (b) Problems associated with the employment and wages; (c) Health and morbidity related problems; (d) Market status and price fluctuations.
This observation brings in a broader thinking about food security including the accessibility to consume insufficient quantity or quality of foods within the society. Household level food security demonstrates the availability of food structures within the households to eradicate the crises related to low level of food consumption of women and other family members (Negin et al., 2009). Food security is the availability of an adequate amount of food and the ability to access the expected proportion of foods at the right time by each individual (Ibharhokanrhowa, 2016). The International Food Policy Research Institute (IFPRI) define food security based on the three sections, such as food production, food access and food utilization. Food security at the household level refers to producing foods for their household consumption and earning additional revenue by selling surplus to the market. But rural women try to adapt to the latest opportunities and constraints regarding the production of foods while ensuring the adequate level of foods within their families (Negin et al., 2009).

Food security has been generally responsible for building up sustainable development throughout the world. Because United Nations already focused as a developmental goal in particular country.

\section{Access to modern farm technologies and food production}

Farming is a multifaceted concept involving the entire cultivation process: clearing the lands, planting, weeding, harvesting, and post-harvesting activities (Ibharhokanrhowa, 2016).

Women has less ability to participate in economic opportunities because they face a work related with social mission rather than the men. In most societies, women are responsible for the household supervision and child-rearing activities and rearing of small livestock. According to the FAO, 2015 report, Novel Sri Lankan Agriculture suffers from several major problems. Such as,
a) Low adoption of modern farming technologies
b) Lower utilization of mechanization
c) Higher level of cost of production and lower profitability
d) Increases in post-harvest losses
e) High amount of transportation cost
f) Lower level of market-oriented products 
g) Poor level of value addition to primary agricultural products

h) Low crop productivity

i) Research \& Development in central government

j) Less priority to extension

More potential benefits are associated with Contract Farming (Bellemare, 2015). Because farm scale tends to be small, farmers are consistent with poor awareness about the agricultural activities, total agricultural production, and utilization of management technologies are less efficient. Infrastructure facilities such as transportation of agricultural inputs and production, and poor flow of information within the supply chain, contracting with a large agribusiness firm may be the only way farmers can access higher-end markets and receive beneficial returns from it (Wang et al., 2014).

Generally two types of farming technologies used; (1) Local farming technology, and (2) Modern farming technology. Local technologies obtain a smallscale manner, conducted simple operations, lower cost, and built up with indigenous materials. When considering modern technology, is consist with large-scale, higher operating cost, overall operational activities conducted as profit-oriented and maintaining with complex operations (Ibharhokanrhowa, 2016).

\section{Extension service and food production}

Rural economy basis with the Agriculture. Agricultural extension is the most prominent type of extension occurred in nonmetropolitan areas (FAO, 2018). In other words, extension is a process related with an informal educational background focused toward the population in non-metropolitan areas. Extension process allows for several advices and dissemination of information to solve their existing problems. Extension aims to optimize the efficiency of the family farming activities, maintain the maximum level of food production, and generally support upgrading the farm family's standard of living and overall development (Ibharhokanrhowa, 2016).

The basic objective of the extension is to build up a proper foundation for farmer's outlook by focusing their opportunities and threats. Extension is not centralized with physical and economic development of the non-metropolitan population. Agricultural extension agents help gain sustainable development by disseminating knowledge with the rural people (FAO, 2018).

An improved information and knowledge flow within the agricultural sector supports improving the small-scale agricultural production and creates a proper path way to optimize the production surpluses to the agricultural markets, increased rural livelihoods, and optimized quality and yield (Mojaki \& Keregero, 2019). Rural farmers obtain very little information regarding the agricultural sector, but innovative modern knowledge occurring in research institutions, universities, public offices, and libraries consist of poor dissemination. It causes to build up the poor linkages between research, extension, not for profit and non-profit organizations, libraries etc. (Lwoga et al., 2011). Most developing countries are suffering from gender inequality focused under millennium development goals, cause to increase the knowledge barrier for the women farmers (Quisumbing et al., 2014).

\section{Access to credit facilities for food production}

The demand for agricultural credit facilities is prevalent by the socio-economic factors in most non-metropolitan areas of developing countries (Yadav \& Sharma, 2015). Most of the low income farmers persuade to accessibility of credit facilities to minimize the financial hazards occurring with the fertilizer and agrochemicals in virtually all developing countries (Rehman et al., 2015).

Research has provided a greater platform for the credit facilities to empower women in taking decisions within the household, having proper social networks, having proper access to financial and economic resources, more bargaining power with their husbands within the family and having considerable freedom of mobility. However, women are still suffering from various difficulties for the accessibility of such credit facilities. The major case of lower accessibility of credit facilities, the rural women has low level of literacy and dependent on their husbands for agricultural inputs (Ibharhokanrhowa, 2016). Agricultural credit obtains several credit vehicles for financing the agricultural transactions, including loans, notes, bills of exchange, bankers' acceptances, etc. These financing methods are supported to the specific financial needs of farmers, which are determined by planting, harvesting, and 
marketing operations. In other words, credit is regarded as a major factor for the both agricultural development and rural development (Martin et al., 2014). Low interest rates of credit facilities for purchasing agricultural productive inputs, deviations of a traditional practice (tenure farming). Therefore, to significantly improve food production, a good agricultural credit system is an essential requirement. The government policy makers are focusing to bloom the sustainable financial system for the development of the agricultural sector. It cause to build up the accessibility of credit and other financial services (including banking) to the rural farmers (World Bank, 2019).

\section{RESEARCH METHODOLOGY}

This research was conducted in Imbulpe DS division of Sri Lanka where many agricultural activities are performed. Questionnaire Survey used as the main data collection method in order to collect primary data. The respondents of the research were the women farmers in Imbulpe DS division.

Around 650 women farmers obtained in Imbulpe area. Among them, 300 women farmers were randomly selected for the study. The purposive sampling technique was adopted to select seven selected GN divisions across the $50 \mathrm{GN}$ divisions in the study area.

Structured questionnaire was used as the primary data collection method of the study. The descriptive statistics and regression analysis analyzed primary Data through SPSS software version 23 .

The seven aspects of women empowerment aggregate to create a unit score of empowerment to compare each aspect of empowerment. The following formula represented a unit score:

Formula 1 Unit empowerment score

Unit score of empowerment $=\underline{\text { Average score of a empowerment aspect }}$

Maximum possible score of the empowerment aspect

Formula 2 Overall empowerment

Overall empowerment $=\underline{\text { Total empowerment }}$

Number of respondents

Seven indicators were selected to identify the relationship of the empowerment of women farmers. Those indicators were demonstrated with the following aspects. Such as personal, economic, educational, social, psychological, technological and political empowerment aspects.

Table 1 Aspects of empowerment of women farmers and their selected indicators

\begin{tabular}{llcc}
\hline $\begin{array}{c}\text { Empowerment } \\
\text { Aspect }\end{array}$ & \multicolumn{1}{c}{$\begin{array}{c}\text { Empowerment } \\
\text { Dimension }\end{array}$} & $\begin{array}{c}\text { Number of } \\
\text { indicators } \\
\text { used }\end{array}$ & $\begin{array}{c}\text { Description of the weighted scores of } \\
\text { each indicator }\end{array}$ \\
\hline $\begin{array}{l}\text { Psychological } \\
\text { empowerment }\end{array}$ & $\begin{array}{l}\text { Decision making within } \\
\text { the family }\end{array}$ & 10 & $\begin{array}{c}\text { 0- No influence, 1- Low influence, 2- } \\
\text { Moderate influence, 3- Full influence }\end{array}$ \\
\hline $\begin{array}{l}\text { Economic } \\
\text { empowerment }\end{array}$ & Spending ability & 10 & $\begin{array}{c}\text { 0- No ability, 1- Low ability, 2- } \\
\text { Moderate ability, 3- Full ability }\end{array}$ \\
\hline $\begin{array}{l}\text { Personal } \\
\text { empowerment }\end{array}$ & Access to resources & 8 & $\begin{array}{c}\text { 0- No access, 1 - Low access, }- \\
\text { Moderate access, 3 - Full access }\end{array}$ \\
\cline { 2 - 4 } & Freedom of mobility & 7 & $\begin{array}{c}\text { 0- Not at all, 1 - Rarely, 2- } \\
\text { Occasionally, 3 - Frequently }\end{array}$ \\
\hline $\begin{array}{l}\text { Social } \\
\text { empowerment }\end{array}$ & Social participation & 7 & $\begin{array}{c}\text { 0- No participation, 1- Seldom } \\
\text { participation, 2- Occasionally } \\
\text { participation, 3- Frequent participation }\end{array}$ \\
\hline
\end{tabular}




\begin{tabular}{llcc}
\hline $\begin{array}{c}\text { Empowerment } \\
\text { Aspect }\end{array}$ & $\begin{array}{l}\text { Empowerment } \\
\text { Dimension }\end{array}$ & $\begin{array}{c}\text { Number of } \\
\text { indicators } \\
\text { used }\end{array}$ & $\begin{array}{c}\text { Description of the weighted scores of } \\
\text { each indicator }\end{array}$ \\
\hline $\begin{array}{l}\text { Technological } \\
\text { empowerment }\end{array}$ & $\begin{array}{l}\text { Access to modern } \\
\text { farming technologies }\end{array}$ & 8 & $\begin{array}{c}\text { 0- No access, 1 - Low access, 2 - } \\
\text { Moderate access, 3 - Full access }\end{array}$ \\
\hline $\begin{array}{l}\text { Political } \\
\text { empowerment }\end{array}$ & Political participation & 6 & $\begin{array}{c}\text { 0- No participation, 1- Seldom } \\
\text { participation, 2- Occasionally } \\
\text { participation, 3- Frequent participation }\end{array}$ \\
\hline
\end{tabular}

RESULTS AND DISCUSSION

Overview of women farmers' sociodemographic factors: The women farmers' socio-demographic factors were reported in Table 2. All the respondents were women; therefore, gender variable is missing in the below data.

Table 2 Socio-demographic factors of women farmers.

\begin{tabular}{lccccc}
$\begin{array}{c}\text { Socio- } \\
\text { demographic } \\
\text { factor }\end{array}$ & $\begin{array}{c}\text { frequenc } \\
\mathbf{y}\end{array}$ & $\boldsymbol{\%}$ & $\begin{array}{c}\text { Socio-demographic factor } \\
\text { frequency }\end{array}$ & $\boldsymbol{\%}$ \\
\hline Age & 14 & 4.7 & No of children & & \\
\hline $20-29$ & 45 & 15 & 0 child & 56 & 18.7 \\
\hline $30-39$ & 93 & 31 & 2 child & 133 & 44.3 \\
\hline $40-49$ & 81 & 27 & 3 children & 85 & 28.3 \\
\hline $50-59$ & 54 & 18 & 4 children & 27 & 9 \\
\hline $60-69$ & 13 & 4.3 & 5 children & 5 & 1.7 \\
\hline $70-79$ & 8 & 2.7 & No formal education & 6 & 2 \\
\hline Marital status & 279 & 93 & Primary education & 47 & 15.7 \\
\hline Single & 13 & 4.3 & Secondary education & 242 & 80.7 \\
\hline Married & 0 & 0 & Tertiary education & 5 & 1.7 \\
\hline Widowed & & &
\end{tabular}

\section{Size of the farm} land(acre)

Family size

(Number of members)

\begin{tabular}{|c|c|c|c|c|c|}
\hline $0-0.5$ & 73 & 24.3 & Less than 3 & 158 & 52.7 \\
\hline $0.5-1$ & 56 & 18.6 & $4-6$ & 135 & 45 \\
\hline $1-1.5$ & 95 & 31.7 & more than 6 & 7 & 2.3 \\
\hline $1.5-2$ & 76 & 25.3 & & & \\
\hline $\begin{array}{l}\text { Monthly } \\
\text { income }\end{array}$ & & & $\begin{array}{l}\text { Monthly income from } \\
\text { Agriculture }\end{array}$ & & \\
\hline $0-20000$ & 25 & 8.3 & $0-20000$ & 27 & 9 \\
\hline $20001-40000$ & 208 & 69.3 & $20001-40000$ & 273 & 91 \\
\hline $40001-60000$ & 67 & 22.3 & $40001-60000$ & 0 & 0 \\
\hline $\begin{array}{l}\text { Number of } \\
\text { training } \\
\text { participated }\end{array}$ & & & $\begin{array}{l}\text { Savings (To purchasing of } \\
\text { agricultural inputs for next } \\
\text { cultivation) }\end{array}$ & & \\
\hline $0-10$ & 101 & 33.7 & $0-1500$ & 9 & 3 \\
\hline $11-20$ & 168 & 56 & $1501-3000$ & 13 & 4.3 \\
\hline $21-30$ & 69 & 23 & $3001-4500$ & 187 & 62.3 \\
\hline $31-40$ & 52 & 17.3 & $4501-6000$ & 91 & 30.3 \\
\hline
\end{tabular}

Source: Field survey May-June, 2019

As per results of table 2, the majority of the respondents were 40 - 49 years, so they have a potential of decision-making ability related to farming and other household matters. Only 
$19.7 \%$ of the respondents were reported less than 40 years. $4.7 \%$ of women farmers reported 20-29 years as their age group. Consider as, less than 30 year's respondents are young $4.7 \%$, in years between 30 - 50 as middle age farmers $46 \%$ and more than 50 years farmers are adult farmers $49.3 \%$. According to the findings highest value represent as adult farmers. Marital status, above table demonstrated from the findings as $2.7 \%$ belonged to the single, married category present highest value 93\% among other respondents. But in questionnaire obtain other two categories. Such as separated and divorced. There was not obtain valid cases in respondent sample for these two categories.

Most of the respondents have only 2 or 3 children. No children obtain as $3 \%$. Because the 8 respondents were single and only 1 respondent in age 20-29 years, they have no children. Respondents level of education, $80.7 \%$ of the respondents were obtain secondary education as highest category and pathetic situation behind these data, $2 \%$ of respondents were consist in no formal education category. Most of the husbands $82.3 \%$ of the respondents are obtain with secondary education, Primary education was $13.7 \%$, and only $2.7 \%$ of husband have not formal education. The statistics on family size revealed that $29.7 \%$ of respondents have 4 persons within the family, $10.3 \%$ was obtained as 5 persons, $44.3 \%$ consist with 3 persons, $5 \%$ occurred in 6 persons within their family. Monthly income, $91 \%$ of income obtain in Rs.20001-40000 highest income present category, Rs.0-20000 category was shows as $9 \%$.

According to the household income and expenditure report -2016 rankings,

$$
\begin{aligned}
& 0-10000 \text { income }=\text { Extreme poor } \\
& 10001-20000 \text { income }=\text { Poor } \\
& 20001-40000 \text { income }=\text { Lower middle } \\
& \text { income } \\
& 40001-60000 \text { income }=\text { Upper middle } \\
& \text { income }
\end{aligned}
$$

Therefore, findings indicate the respondents' monthly income and monthly income from agriculture obtain in the lower middle-income category in the study area.

\section{Women Empowerment Aspects:}

Women empowerment measured by using the aspects given bellow.

Table 3 Women Empowerment Aspects

Unit

Empowerment aspect empowerment

score

\begin{tabular}{lc}
\hline Personal empowerment & 2.71 \\
\hline $\begin{array}{l}\text { Economic } \\
\text { empowerment }\end{array}$ & 2.54 \\
\hline $\begin{array}{l}\text { Educational } \\
\text { empowerment }\end{array}$ & 2.62 \\
\hline Social empowerment & 2.8 \\
\hline $\begin{array}{l}\text { Psychological } \\
\text { empowerment }\end{array}$ & 2.69 \\
\hline $\begin{array}{l}\text { Technological } \\
\text { empowerment }\end{array}$ & 2.41 \\
\hline Political empowerment & 2.29 \\
\hline Source: Field survey May-June, 2019
\end{tabular}

According to the formula 2, Overall empowerment $=2.58$

Each aspect of the unit empowerment score categorized into five levels. These levels are weighted as 1 to 5 according to their ascending order of unit empowerment score. As per the table 2, most of the respondents were showed social empowerment and political empowerment aspect by the least number of respondents in the study area. And also, personal, educational and psychological empowerment aspects were reported higher unit empowerment score values than other selected aspects.

Factors affecting women Empowerment: Analysis done using descriptive statistics and step wise multiple regressions analysis. Independent variables are age, education in years, family size, Land size, number of training attended, monthly income, experience in agriculture in years, number of participated organizations in the village, number of extension services used, number of credit facilities used. Empowerment score act as the dependent variable of the study. Other factors relevant to the empowerment score, consider their relationship strong from the correlation coefficient $(r)>0.05$. 
Table 4 Identification of the relationship of unit score of empowerment of women farmers and predictable variables

\begin{tabular}{lc}
\hline \multicolumn{1}{c}{ Independent variable } & Correlation coefficient $(\mathrm{r})$ \\
\hline Education & 0.644 \\
\hline Size of the farmland & 0.376 \\
\hline Experience in Agriculture & 0.121 \\
\hline No of organizations participated & 0.243 \\
\hline No of training attended & 0.477 \\
\hline Age & 0.307 \\
\hline Monthly income & 0.136
\end{tabular}

Source: Field survey May- June, 2019

Table 5 Percentage variation of women's empowerment score with the selected predictable variables based on the stepwise multiple regression analysis.

\begin{tabular}{clccc}
\hline \multirow{2}{*}{ Model } & \multicolumn{1}{c}{ Variable } & $\begin{array}{c}\text { Multiple } \\
\mathrm{R}\end{array}$ & $\begin{array}{c}\text { Coefficient of } \\
\text { determination R square }\end{array}$ & $\begin{array}{c}\text { Percentage } \\
\text { variation expressed }\end{array}$ \\
\hline 1 & Education & 0.734 & 0.620 & 62 \\
\hline 2 & No of training attended & 0.779 & 0.601 & 60.1 \\
\hline 3 & Size of the farmland & 0.793 & 0.536 & 53.6 \\
\hline 4 & Monthly income & 0.799 & 0.628 & 62.8 \\
\hline
\end{tabular}

Source: Field survey May- June, 2019

The monthly income of the respondents had been explained the highest percentage variation as $62.8 \%$, Education represents the $62 \%$ variation and number of training attended indicate $60.1 \%$ variation. Therefore, monthly income, number of training attended, education, and farm land size affect the empowerment of person. Farm women's empowerment impact on food production was analyzed using the above four factors. Therefore cultivable land size, utilizing modern farming technologies, agricultural extension program participation and credit accessibility were selected as the independent variables to analyze farm women empowerment on food production in the study area.

Impact of the cultivable land size and food production: Research findings were noted as $50.7 \%$ of respondents had less than 0.5 -acre farm land and 2-acre size was the largest acreage of farm land that showed by the respondents $2.8 \%$ within the study. Cultivable land size and food production impact were assessed through the chi-square analysis. The P-value of Pearson Chi-Square value is 0.007 which is less than the significance level (0.05). And also, the relationship is moderate $68.7 \%$, we conclude that there is an association between cultivable land sizes to the food production in the study area. Even though the farm land size increases food production may be less, the way of using agricultural inputs, farming experiences of the respondents, location of the farm land and soil structures and adequate agricultural extension services. According to the findings of the Sraboni at al., 2014 noted that the availability of cultivable land size varies the respondents' level of household food security.

\section{Impact of utilizing modern farming} technologies and food production: Most respondents had less than 1-acre farmland and utilization of modern farming technologies obtained as considerably very low in the study area. Therefore, hybrid seeds, seedlings, ploughing equipment, and plant growth regulators were used as modern farming technologies. Research findings showed that $53.3 \%$ of respondents utilize modern farming technologies while doing their cultivations and $46.7 \%$ of respondents did not use any modern farming technique for their cultivations. The chi-square analysis assessed the utilization of modern farming technologies and food production impact. The P-values of Pearson Chi-Square value is 0.08 and Cramer's chisquare value 0.08 which is not less than the significance level (0.05). And also, the relationship is at lower level $38.7 \%$, we 
conclude that there is not a considerable association between utilization of modern farming technologies to the food production in the study area. According to the findings of the Ibharhokanrhowa, 2016; FAO, 2013 showed that level of food production has an up-warding potential through the utilization of modern farming technologies increases the quantity of food produced by the rural women farmers.

Impact of agricultural extension program participation and food production: $62.1 \%$ of the respondents were gained benefits from the agricultural extension services in Imbulpe area, as only $39.9 \%$ of respondents were reported that they never attended for any kind of agricultural training. There are four factors to justify their absence for the agricultural extension programs. Such as (a) Not registered in the any agricultural organization (b) Financial constraints (c) Not invited to me (d) Not important to me (e) Not enough time. Most of the respondents $50.4 \%$ answered as not registered in any agricultural organization.

Agricultural extension program participation and food production impact were assessed through the chi-square analysis. The P-values of Pearson Chi-Square value and Cramer's V test is 0.000 which is less than the significance level (0.05). And also, the relationship is very strong (0.977), we conclude that there is an association between agricultural extension program participation and farmer education to the food production in the study area. Chisquare analysis of the relationship between Agriculture extension services accessibility and food production. But according to the Abbeam et al., 2018; Ibharhokanrhowa, 2016 findings, participation of agricultural extension \& training programs consists with the positive impact on food production capacity of rural women farmers.

Impact of credit accessibility and food production: Only $18.6 \%$ of the respondents have a possibility of the accessibility of any kind credit facilities. Most respondents did not access loan was were Such as, fear of inability to do the settlements $49 \%$, the frustration arising from the bank's demand for collateral $18.6 \%$, and larger interest rates of the bank $28.3 \%$. Most of the respondents among those who access loan facilities, reported as loan accessed before one year ago or two year ago. Because, most of the respondents find initial capital through bank loans. After that, they keep savings to purchasing agricultural inputs to the next cultivation. And also, those who accessed loan, $7.6 \%$ of respondents' highest category present as Rs.25000-50000. Rarely reported more than Rs.50000 loan amount. Impact of credit accessibility on food production revealed that all the respondents (11\%) who had obtained the loan for one or more years reported an increase in food production as less than double. 5.5\% respondents reported as convert their food production double after the credit accessibility. Only 1 respondent indicate as increase their food production more than double. The other respondents reported no increase from their loan without fully utilization of it. Because it has been less than a year ago. The women responded that lower accessibility of credit facilities acts as the enormous barrier to upward the level of food production because they do not have adequate funding to purchase the required agrochemicals, fertilizers, pay for farm labor, and so on. But the level of food production cannot increase considerably, even if the possibility was obtained to access any kind of credit facilities by the women farmers.

Credit accessibility of respondents and food production impact were assessed through the chi-square analysis. The P-values of Pearson Chi-Square value and Cramer's V test is 0.000 which is less than the significance level (0.05). And also, the relationship is very strong (0.954), we conclude that there is an association between accessibility of credit facilities and food production in the study area. According to the findings of the Ibharhokanrhowa, 2016; Aina, 2012 showed that accessibility of credit facilities increases food production among rural women farmers.

\section{CONCLUSION}

Based on the study findings, women farmers in Imbulpe DS division are medium empowered in their efforts in food production. Freedom to make decisions within the family involves contributing more weight to the empowerment than the other factors. Such as, spending ability, social participation, access to assets and resources and freedom of mobility. Other factors responsible for the empowerment are highlighted as education, monthly income and number of extension services participated. Under empowerment, poor access to modern 
agricultural techniques is engendered by improper institutional participation failures. They have not enough money to spend on modern farming equipment and poor knowledge about the innovative agriculture. Most of the women farmers gain their farmland through their husbands. Accessibility of credit facilities and agricultural extension program participation showed a considerable impact on food production rather than the cultivable land size and utilization of modern farming technologies for food production.

\section{REFERENCES}

Abbeam G. D., Ehiakpor D. S., \& Aidoo R. (2018): Agricultural extension and its effects on farm productivity and income: insight from Northern Ghana. Agriculture \& Food Security, 7(74).

doi:https://doi.org/10.1186/s40066018-0225-x

Aina O. I. (2012): Two halves make a whole: Gender at the Crossroads of the Nigerian Development Agenda. An Inaugural Lecture Delivered at the Oduduwa Hall, Obafemi Awolowo University, Ile-Ife, Nigeria. Obafemi Awolowo University Press Limited.

Annual Labor Force Report. (2017): [Accessed on 04/07/2020]. Available at: http:// www.statistics.gov.lk/samplesurvey/ LFS_Annual\%20 Report_2016.pdf

Bellemare M. F. (2015): Contract Farming: What's In It for Smallholder Farmers in Developing Countries? Agricultural \& Applied Economics Association, 30(3). Retrieved from http://www.choicesmagazine.org

Central Bank Reports. (2018): Economic social science statistics. [Accessed on 04/07/2020]. Available at:https://www.cbsl.gov.lk/en/public ations/economic-and-financialreports/annual-reports/annual-report2018.

Food and Agricultural Organization of the United Nations (2013): Forests, food security and gender: linkages, disparities and priorities for action. Background paper for the International Conference on Forests for Food Security and Nutrition Forests for Food Security and
Nutrition. World Bank. Available at: http://www.fao.org/publications/sofa /2013/en/

Food \& Agriculture Organization reports,.(2015): [Accessed on 04/07/2020]. Available at: http://www.fao.org/publications/sofa /2015/en/.

Household income and expenditure survey reports,. (2016): [Accessed on 04/07/2020]. Available at: http://www.statistics.gov.lk/ agriculture/

Ibharhokanrhowa o. m. (2016): Empowerment of Rural Women Farmers and Food Production in Esan West Local Government Area of Edo State, Nigeria. A Thesis Submitted in Partial Fulfilment of the requirements forthe Degree of Doctor of Philosophy (Ph.d) in Sociology to the Department of Sociology, College of Business and Social Sciences Covenant University . Available at: http://eprints.covenantuniversity.edu. ng/8494/1/ozoya\%20mercy\%20i\%20 phd\%20thesis.pdf

Lwoga E.T., Ngulube P. and Stilwell, C., (2011): Access and use of agricultural information and knowledge in Tanzania. Library Review 60(5): 385395. http://www.emeraldinsight.com/

Martin O. (2013): The African Union's mechanisms to foster gender mainstreaming and ensure women's political participation and representation. Sweden: International IDEA.

Maxwell S. Smith M. (1996). Food security: A post-modern perspective. Food Policy 21(2), 155-170.

Millenium Development Goals reports,. (2015): [Accessed on 04/07/2020]. Available at:https://www.un.org/millenniumgo als/2015 MDG Report/pdf/MDG\%2 02015\%20rev\%20(July\%201).pdf

Mojaki R. A., \& Keregero K. (2019): Turning challenges into opportunity: Potential for adoption of e-extension in Lesotho. Journal of Agricultural Extension \& Rural Development, 11(11), 184-191. doi:https://doi.org/10.5897/JAERD2 019.1040 
Negin J., Remans R., Karuti S., \& Fanzo J. C. (2009): Integrating a broader notion of food security and gender empowerment into the African Green Revolution. Food Security, 1, 351360. doi:10.1007/s12571-009-0025-z

Parveen, S., \& Leonhäuser, I.-U. (2004). Empowerment of Rural Women in Bangladesh: A Household Level Analysis. Conference on Rural Poverty Reduction through Research for Development and Transformation- Deutscher Tropentag-Berlin, 5-7 October 2004. Quisumbing A. R., Dick R. M., Raney T. L., Croppenstedt A., Behrman J. A., \& Peterman A. (2014): Gender in Agriculture: Closing the Knowledge Gap. The Food and Agriculture Organization of the United Nations \& Springer Science. doi: 10.1007/97894-017-8616-4

Rahman H., \& Naoroze K. (2007): Women empowerment through participation in Aquaculture: Experience of e large scale technology Demostrain project in Bangladesh. . Journal of social science.

Rathnachandra, S., \& Malkanthi, S. (2020). Management activity of women farmers in Imbulpe DS division in Sri Lanka: A Household Level Analysis. Икономика и управление на селското стопанство, 65(2), 7075.
Rehmana A., Jingdong L., Shahzad B., Chandio A. A., Hussain I., Nabi G., \& Iqbal M. S. (2015): Economic perspectives of major field crops of Pakistan: An empirical study. Pacific Science Review B: Humanities and Social Sciences, 1(3), 145-158. doi:https://doi.org/10.1016/j.psrb.201 6.09.002.

Sraboni E., Malapit H. J., Quisumbing A. R., \& Ahmed, A. U. (2014): Women's empowerment in agriculture: What role for food security in Bangladesh? World Development, 61, 11-52.

Wang H.H., Y. Wang and M.S. Delgado. (2014): "The Transition to Modern Agriculture: Contract Farming in Developing Economies," American Journal of Agricultural Economics 96(5): 1257-1271.

World Bank. (2019, September 23): Agriculture Finance \& Agriculture Insurance. [Accessed on 04/07/2020]. Retrieved from https://www.worldbank.org/en/topic/ financialsector/brief/agriculturefinance.

Yadav P., \& Sharma A. K. (2015): Agriculture Credit in Developing Economies: A Review of Relevant Literature. International Journal of Economics and Finance, 7(12), 219-244. doi:10.5539/ijef.v7n12p219. 